\title{
WOVEN IDENTITIES: SOCIOECONOMIC CHANGE, WOMEN'S AGENCY, AND THE MAKING OF A HERITAGE ART IN JØLSTER, NORWAY
}

\author{
SALLIE ANNA STEINER \\ PhD Candidate in Folklore Studies \\ Department of Comparative Literature and Folklore Studies \\ University of Wisconsin-Madison \\ 2402 Sterling Hall, 475 North Charter Street \\ Madison, WI 53706-1507, USA \\ e-mail: sasteiner2@wisc.edu
}

\begin{abstract}
This article* focuses on the recent history and contemporary practice of a kind of traditional tapestry weaving known as smettver in the rural county of Jølster in mountainous western Norway. Jølster has a rich fibre arts tradition and a rapidly changing society and economy, which make it an exemplary study in material culture as its fibre arts transform to accommodate these changes. This article draws on ethnographic research and interviews with representative practitioners and community members to examine how conceptions about producer and audience identity and the role of this art form in everyday life have evolved in light of changing context. The article furthermore discusses the ways in which the forms and motifs associated with smettvev are being re-appropriated by local contemporary artists working in other mediums, as well as by individuals and institutions who see smettver as a symbol of local identity and heritage.

KEYWORDS: material culture $\bullet$ fibre arts $\bullet$ weaving $\bullet$ heritage $\bullet$ identity $\bullet$ rural studies
\end{abstract}

I first travelled to Jølster in 2012 while living in the northern Norwegian city of Tromsø. My family had immigrated from Jølster to the United States in the 1920s, and I grew up surrounded by stories and artefacts from Jølster, a location my American family members continue to refer to as "the home place". I had been familiar with the names and faces of my Norwegian relatives through the letters and Christmas cards our respective sides of the family had dutifully exchanged, but got the opportunity to meet them faceto-face for the first time in 2012. During my visit, I became acutely aware of the absence of women's voices in the 'official' histories and genealogies presented to me, as men's names and stories seemed to dominate the written records. Conversely, I was struck by the quiet but tangible presence of female ancestors in the form of the colorful a $\mathrm{kler}^{1}$ that decorated relatives' homes, and was intrigued by how my inquiries into the tapestries often brought out stories and anecdotes about the matriarchs who had made them.

\footnotetext{
* This research was supported by the Mellon Area and International Studies Fellowship.
} 


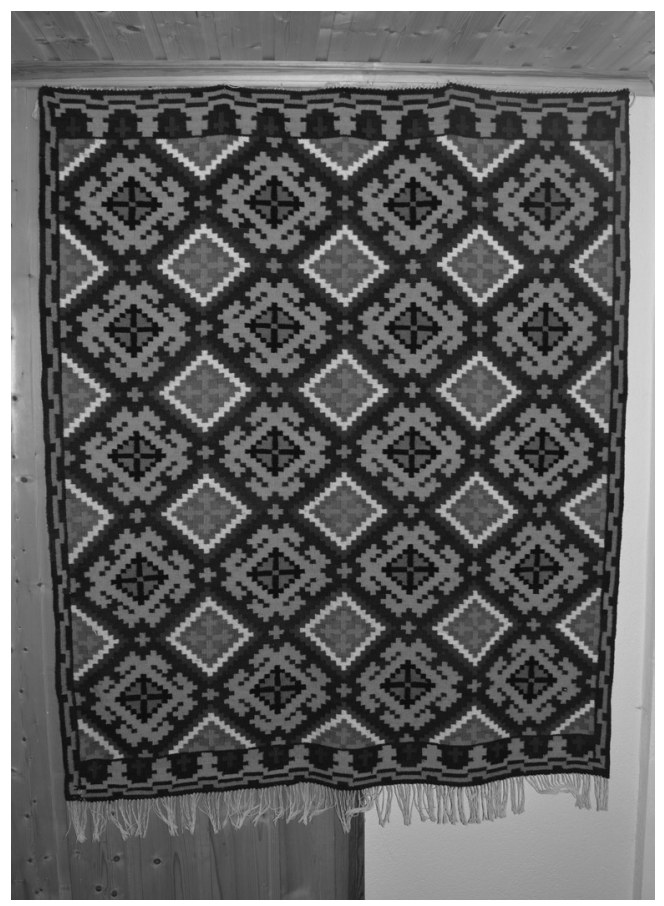

Photo 1. An åkle by Jorunn Dvergsdal, done with a pattern distinctive to her native village of Myklebust $i$ Jølster. Photo by the author.
In observing how my relatives interacted with and talked about smettvev ${ }^{2}$ textiles (see Photo 1), I became fascinated by the position these objects held as a heritage art and tangible placeholder for memory. I saw in my relatives' relationships with inherited tapestries a memorialising of ancestors. While the physical realities of these material objects remained the same, their significance had transformed over time as they developed in relation to the lives of the producers and audience, taking on new meaning as heritage objects in light of contemporary situation (Glassie 1973; Williams 1977: 116; Mondale 1994: 17).

Thus, my study into contemporary smett ${ }^{3}$ weaving in Jølster begins with some key questions: What does it mean to call something heritage? More specifically, when does a cultural phenomenon or practice go from being a normal, everyday part of life to something a group of people re-appropriate to symbolise themselves, to encapsulate their identity?

I explored these questions during fieldwork conducted in the summer of 2014, as I examined the evolving role of smettvev in relation to socioeconomic changes in Jølster over the past century, and was particularly interested in the relevance of this traditional craft in the globalised lives of contemporary jølstringar. ${ }^{4}$ As I spent time in the area and witnessed how traditional weaving is being practiced and understood by younger generations, I became aware of the ways in which jølstringar utilise this craft and its associated symbols to perform identity. My observations led me to surmise that, whereas smettvev had fulfilled subsistence and ritual needs in previous generations, its current social position is largely that of heritage art and identity symbol. Younger generations of contemporary occupational weavers are motivated largely by their interest in this traditional form as a heritage art, even as some continue to rely on it for economic viability. This indicates a profound change in how smettvev is perceived by jølstringar; a reflexive reinterpretation - brought on by socioeconomic change - of this material form as heritage.

My research and analysis takes its cue from folklorists who have increasingly examined the impact of warfare, migration, creolisation, and changing political and economic structures on the traditional practices of discrete groups. Indeed, folklorists have come to understand that the persistence of tradition requires the dynamic interplay of continuity and change; and that tradition is fundamentally a process imbued with agency through which the past is used to shape the future in light of contemporary political, social, and economic forces (Widbom and Klein 1994; Glassie 2003: 176-177). 
Post-colonial theorists have likewise argued that the impact of the global economy has not created a more homogenous world, but rather that groups of people have found traditional ways to localise globalisation by creating and performing highly local cultural forms through which they relate to and interpret the larger global context (Appadurai 1996). Folklorists and scholars in the humanities and social sciences have often engaged the intersection of global economies and local traditions either by critiquing the interventions of entrepreneurial outsiders and acquisitive consumers (Whisnant 1983; Becker 1998; Kirshenblatt-Gimblett 1998) or, more recently, by advocating ethical economic development on behalf of local communities (Hufford: 1994; Seitel 2001; Urban Institute and Fund for Folk Culture 2003; Feltault 2006). Folklorists furthermore recognise that people use their past to shape their future in light of contemporary political, social, and economic contexts (Glassie 2003: 176-177). Therefore, comprehending the cultural impact of and response to economic situations necessitates an understanding of tradition as a mode of social engagement and agency by the folk.

My research furthermore takes its cue from scholarship on ethnographic reflexivity. Scholars argue for the need by ethnographers to understand the intersubjective relationships between themselves and their collaborators, focusing on how their own sociocultural placement impacts the context in which they do fieldwork (Salzman 2002). My application of reflexive theory in this study differs from this ethnographercentred approach, however. I wish to use reflexivity to talk about the experiences of my Norwegian collaborators and specifically to show how jølstringar shape their identities through reflections upon self and community, drawing my inspiration from Alan Dundes' (1966: 51) call to "elicit the meaning of folklore from the folk". This shaping and understanding happens as reflexivity catalyses a "turning-back of the experience of the individual upon [themselves]" and thus is instrumental in "the development of the mind" and of perceptual identity (Strauss 1956: 211). I will demonstrate that the reinterpretation of smettvev as a heritage art in Jølster is a product of this reflexive phenomenon, which I term folk reflexivity. Furthermore, I will show that jølstringar's folk reflexivity has been strongly influenced by socioeconomic changes in that community over the past century.

Over the course of the summer of 2014, I engaged in fieldwork amongst a diverse group of people ranging in age from 11 to 102, all with differing levels of engagement in fibre arts. My collaborators were occupational weavers, hobby weavers, shopkeepers, community researchers and collectors, grandparents who had grown up weaving, and the grandchildren onto whom they had passed their craft. ${ }^{5}$ In my conversations with these collaborators, I was continually struck by the avalanche of changes in the region brought on by the increasing wave of globalisation and capitalisation that has poured steadily into the area since the early 20th century. Through their narratives, I saw how the shifting economy, landscape, and growing mobility of the people had in turn shaped developments in their weaving tradition. I noted how locals responded to socioeconomic changes in Jølster over the past hundred years by transforming traditional fibre arts from crafts done to sustain the physical wellbeing of the people, to intangible cultural heritage that validates, defines, and sustains their identity. In this way, smettvev may be seen not only as embodying a social life of its own in this rural Norwegian district, but also as playing a role in shaping the larger social imaginary of jølstringar as they seek to understand themselves reflexively through the re-appropriation of this art and its associated symbols (Appadurai 1996: 31). 
In analysing my research, I identified three eras in the emergence of fibre art heritage in Jølster as narrated to me through the living memory of my collaborators: pre1945, when a subsistence economy dominated and weaving was an integral part of traditional lifeways; 1945-1980, when the economy began to shift dramatically towards a capitalist structure and a cottage weaving industry emerged; and finally 1980-present, which finds Jølster now fully integrated into the global economy and smettvev seen decidedly as a heritage art. Writing about how constructed events like museum exhibits and folklife festivals effect perceptions of cultural identity, James Abrams (1994: 26) refers to the shift from everyday cultural phenomenon to heritage practice as "cultural objectification." He defines this to mean "the process of reifying previously taken-for-granted behaviours as cultural property and turning them into a medium for exchange". Abrams' observations on heritage in the context of exhibitions apply to my understanding of heritage as it is formed through folk reflexivity in Jølster. Certainly, in becoming a symbol for identity, smettvev has transformed into a means of communicating about ("exchanging") identity. Furthermore, as the society and economy of Jølster have transformed to fit the capitalist model, value is increasingly ascribed according to the ability of something to be exchanged, whether in the commodity sense or in the sense of performing identity.

\section{0-1945: AN ERA OF SUBSISTENCE}

Before and during World War II, Jølster was an insular community with an intrafamily subsistence economy that had evolved from the breakdown of the previously dominant feudal system. Capitalism and globalisation had begun to creep into the area en masse towards the end of the 19th century, as the founding of banks in several communities in the 1890s and first decade of the 1900s attests (Førsund 2001). ${ }^{6}$ Automobile roads, stores, and companies involved in importing and exporting goods and people to and from Jølster had also sprung up, but by-and- large the life of the average resident of this rural community remained dictated by the same socioeconomic structures that had been known in the region for centuries. Collaborators of my project born before World War II described growing up with traditional farm and familial structures and following traditional calendar cycles that dictated every aspect of work and play in their agricultural communities. For women of this era, the year was largely split between agricultural work in the warm months and textile work in the long night of winter.

According to my collaborators, weaving was a subsistence craft in this period performed to produce necessary fabrics and more decorative items needed to fulfil ritual practices. These included bridal coverlets called brureåkler ('bridal tapestries') woven in smett by brides-to-be or by other family and community members as wedding gifts or dowry items (see Photo 2). Svanhild Åhaug (b. 1921) of Ålhus remembered weaving her first smettåkle in preparation for her wedding. She said the åkle was hung up as decoration in the church during the ceremony and in the ungdomshuset, a community social space, for the reception. Other sources told me that the brureåkle was used as a coverlet on the wedding bed, its symbolic patterns and motifs imbuing the new relationship with luck, fertility, and happiness.

Pre-World War II collaborators like Svanhild narrated for me the yearly cycle of textile work, the preparations for which began in the spring when the sheep were shorn 
for the first time. This was traditionally men's work, but also often fell upon women, demonstrating that gender roles in Jølster are often more fluid than idealised social conventions would indicate. Svanhild noted proudly in our interview that her mother always sheared her own sheep. After this initial shearing, the wool would be stored, for there was too much outdoor work to be done in the warmer months to bother with handicrafts. Once the fall harvest was over, the sheep would be shorn again. Then carding equipment and spinning wheels would be brought into the house from a storage building called the eldstove and the women would begin spinning it into yarn. Svanhild said that wool from different times of the year had different consistencies and thus different purposes. Spring wool was softer and used for weft, while fall wool was short and coarse and best for warp. The women had until Christmas to finish

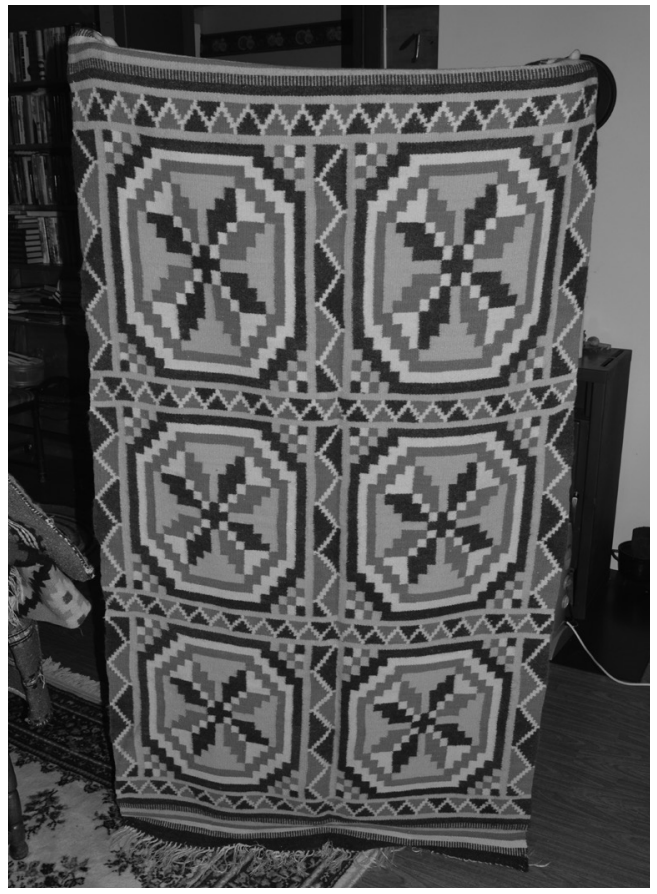

Photo 2. Svanhild Åhaug's brureåkle, ca. 1940. Photo by the author. preparing the wool, and then the looms would be brought into the main house so that they could begin weaving. Necessities would be woven first.

Brita Kongsvik (b. 1929) of Myklebust said her family would weave fabric for women's clothing as well as men's work and sleep clothes. Dress clothes for men would have to be purchased from a travelling tailor, as their presence in public life necessitated their use of more cosmopolitan dress. The women would also weave blankets, like kvitla. ${ }^{7}$ By the time Svanhild and Brita were born, most local women had abandoned natural homemade dyes and were using synthetic, store-bought versions to colour their yarn and cloth. However, the practice of dying the yarn used for weaving blue stripes into the kvitla with potteblatt, a dye made by mixing fermented urine with natural blue plant dyes like indigo, was still known by Brita.

If there was still time left after the essentials had been woven, the women would begin on decorative and ceremonial items like brureåkler. Svanhild said that brides-tobe were often made exempt from weaving necessary items so that they could focus on weaving wedding coverlets and other textiles for their dowries. In addition to their use in wedding ceremonies, smettåkle were also often hung on the walls of the main house, serving both as decoration and as insulation. Brita and Svanhild both stressed that all weaving had to be completed a bit before Easter, as the looms needed to be taken out of the main house so that spring cleaning could begin in time for the holiday season. Svanhild indicated that the timeframe dictating the presence of the loom in the house was almost taboo-like. After Easter, the sheep would be shorn anew and the cycle would begin once again. 
By the time these women were born, age-old textile folklore had already begun to break down and change as Jølster became increasingly globalised. The new-andimproved roads brought novel ideas to the community, which led to rapidly changing aesthetics for locals. This in turn brought a shift in ceremonial traditions involving textiles. While several of my collaborators mentioned having woven brureåkler for their own weddings in the 1940s and 1950s, they indicated that this tradition was on its way out by the time they had grown to adulthood. From our conversations, it seemed that women in their mothers' generation, who married in the first two decades of the 20th century, had been the last to practice this tradition by default.

While decorative and ceremonial uses for textiles had declined sharply in this period, it appears that the traditional cycle of textile work and the production of more utilitarian textiles was kept alive by need during World War II. My collaborators indicated that rationing during these years necessitated their reliance on traditional subsistence models, and thus whatever headway locals had made in becoming more connected with the global import-export economy in the pre-war years was sharply curtailed under German occupation. They said that wool continued to be spun and textiles woven throughout the war, and that completed textiles were used until they were worn out. As had been a common practice for generations, old blankets and tapestries would often be recycled to create new objects or retired to the barn, where they were used as blankets for horses.

\section{5-1960: AN ERA OF PRODUCTION}

The post-war economic boom that stimulated the economies of many countries also came to Norway, and Jølster returned to the globalising trends that had begun to shape its society in the first decades of the 20th century. Brita Kongsvik indicated in our interview that her first encounter with hard currency happened after World War II, and all agreed that the post-war years brought much more economic capital to the region. Suddenly, value in the society began to shift from the self-sufficiency of family units to the purchasing power of individuals. Emphasis was increasingly placed on selling goods for export to larger cities like Bergen, and more and more the family unit was sustained not through homemade goods, but rather with food and fabric purchased with the money acquired by selling goods for export. Women were caught in a tough spot as economic realities changed. Few women worked outside the home or possessed skills marketable outside the domestic sphere they had occupied for generations. Despite this, women felt the pull to make money like everyone else, and many began to weave for production and sell their wares. Sale of traditional weavings, particularly smettåkler, had been on-going since the turn of the 20th century, but the industry took on a new identity in the post-war years. Before the war, only a few local outlets that catered to tourists, like Hotel Mundal in Fjærland, employed women weavers. Most women who wanted to sell their wares before the war had to know someone in a city like Bergen or Oslo willing to act as a middleman between them and the urban markets. In the 1950s however, local entrepreneurs opened stands and shops selling smettvev products, and a localised, predominantly female-driven curation of art traditions in light of external socioecomic pressures and market forces resulted (Swain 1993). 
An important local person in this movement was Audhild Viken (19152000) of Skei i Jølster. Though she was no longer living at the time of my fieldwork, Viken's legacy was one I encountered continually during my summer in Jølster. Conversations with her son, Hallvard, and daughter-in-law, Eli, gave me further insight into Audhild's life story. Faced with the prospect of supporting her family on her own after her husband became sick and unable to work in the 1950s, Audhild brought some of her tapestries to market in a nearby city. ${ }^{8}$ She found to her surprise that she was able to turn a good profit, and returned to Jølster inspired to continue weaving for production. Audhild eventually started biking around Jølster, buying up weavings from other women to bring to market or to sell at roadside stands. As her business grew, she purchased a building in Skei and opened Audhild Vikens Vevstove. ${ }^{9}$ The choice of this name for her

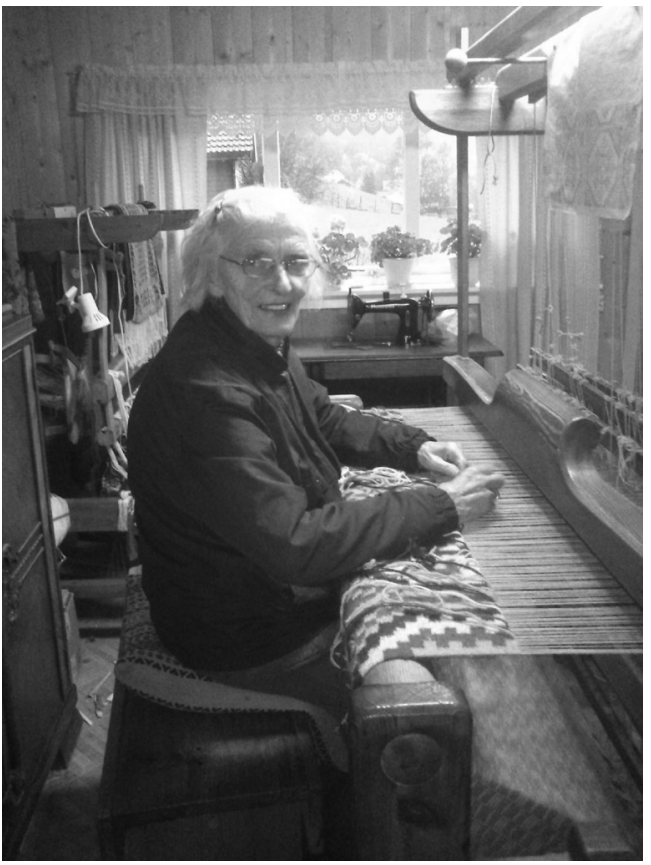

Photo 3. Jorunn Dvergsdal at her loom in the autumn of 2014. Photo by Hans Jørgen Øygard. business demonstrates how Audhild, like many entrepreneurs peddling regional products, used nostalgia to her advantage in the marketplace (Brady 1994: 142).

Audhild Viken has been an important source of income for many women in Jølster over the years. Even some men have been employed weaving for Viken, like Zakarias Dvergsdal, who had also learned to weave when he was a child. According to their daughter Margrete, Zakarias and his wife Jorunn (b. 1929) wove side by side for years, producing large tapestries for Viken. At the time of my research, Jorunn was still weaving for the shop, which is currently operated by Hallvard and Eli Viken. ${ }^{10}$ (See Photo 3.)

Svanhild told me that the income she received weaving for Audhild Viken allowed her greater independence than her mother or grandmother before her. She said making her own money helped her to retain her independence even after marrying. Before this time, women had few property or monetary rights. Traditionally, they were expected to come into a marriage with a dowry of textiles and other useful items that would become part of their husband's property. Women would also usually leave their own families and move to their new husbands' farms. Svanhild was frustrated by this fate, especially given how women of her generation were gaining more opportunities in education and employment. She commented in our interview on how her marriage had brought an abrupt end to her life as a modern working girl in the meieri: ${ }^{11}$

I was used to making my own money because I was 'younger', you could say, and then suddenly something changes, no way! My neighbour, she used to say that when we were younger, we took care of ourselves and used our money as we 
pleased. When we got married, then suddenly we were nothing! She was kind of right, you know.

Svanhild said that it was this frustration that inspired her to start weaving for Audhild Viken. Svanhild said she would get about 1,100 kr for a large, wedding-style tapestry, ${ }^{12}$ and often used this money to buy luxuries, like store-bought birthday presents, which she said had previously been inaccessible to her as an economically isolated married woman.

This new focus on production changed the way traditional weaving was practiced in Jølster. Audhild Viken provided looms and materials to women interested in weaving for her, which both standardised and streamlined the process. Svanhild mentioned that both she and her mother, Johanne (who also wove for the shop), stopped processing their own wool and spinning yarn when they started weaving for Audhild Viken. Svanhild says she only wove for Audhild in the winters as she had farm work to contend with during the warmer months. However, while she kept to the traditional cycle of textile work out of ease, she did not follow the ritual taboos of moving the loom into the house after Christmas and out again by Easter. Instead, she said it was easier to just leave her loom set up year-round. She said she appreciated this new freedom because, in her words, "we didn't want to be slaves".

In addition to providing materials, Audhild Viken also collected and distributed patterns to weavers around Jølster. Weavers had relative freedom in their productions, but were usually tasked with weaving certain kinds of textiles based on their experience level and equipment. Many patterns the weavers used were traditional, but others were more nuanced. While even traditional patterns had certainly changed as styles came into and out of vogue in previous generations, my conversations with weavers indicated that innovation seemed to occur with greater frequency in the post-war era. Svanhild noted that the more "secular" purpose of these textiles allowed individuals to get creative with their designs and fashion interpretive pieces she and others referred to as fantasiåkler ('fantasy tapestries'). Scholars have elsewhere documented this kind of innovation in traditional arts produced for an outsider or tourist audience (Whisnant 1983; Causey 1999). (See Photo 4.)

Ceremonial uses for textiles were still known in the post-war years, but by the time women like Svanhild, Brita, and Jorunn had daughters of their own, it was relatively rare for brides to weave brureakkler. Only Svanhild mentioned that her daughter had used a brureåkle for her wedding in the 1960s. The tradition of giving smettakkler and other textiles for weddings remained, but my informants indicated that these items tended to be woven by someone other than the bride, such as an older female relative. ${ }^{13}$ The rise of weaving collectives in the post-war years also led some locals to purchase these ceremonial items rather than making them at home.

Aesthetics in weaving also changed to fit the new consumer base, which during this time included locals, Norwegians from outside the area, and tourists. Large, traditional smettåkler were still purchased, but because of their cost and the diminishing importance of their ritual significance, weavers had to alter the products they made to fit the needs and desires of customers. Smaller items like table runners thus became popular. The practice of weaving more utilitarian items like kvitla likewise fell by the wayside, as all-purpose, factory-made blankets could now be purchased, and outsiders were more 
interested in colourful, eye-catching smett pieces. I think it is telling that I could not find a single person in Jølster still weaving kvitla in the summer of 2014.

Many of the people weaving for production in the post-war years had learned the craft at home when it was still part of the subsistence model. However, a new generation who had not grown up with this art form was coming to the fore, and accommodations had to be made to teach the craft to younger production weavers. Audhild Viken's collaborator Aud Sunde (1930-2007) travelled around Jølster giving lessons to local women who wanted to weave for the shop. It was also around this time that home crafts began to become institutionalised in the area with the founding of trade schools teaching domestic arts. The Heimyrkjeskule (Home Trades School) in Vassenden i Jølster, was founded in 1945, and many of the women I spoke with in my research, including Jorunn, had been educated there. Schools like this brought a new perspective to the

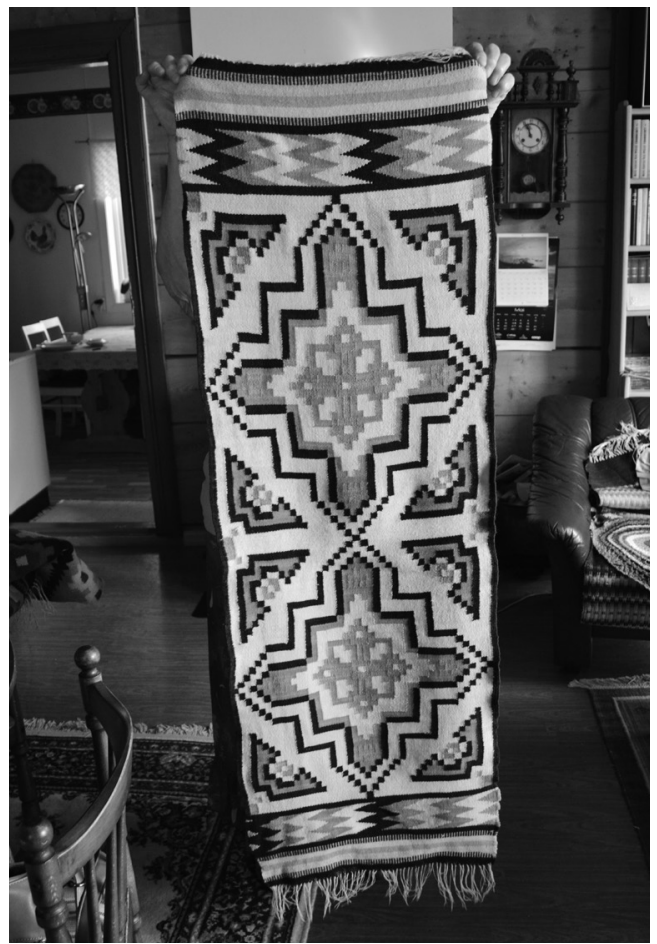

Photo 4. A fantasiåkle by Svanhild Åhaug, circa 1960. Photo by the author. art as they stressed learning the theory and mechanics of weaving above tradition and taught students forms of weaving not native to the area. Jorunn indicated that forms of weaving seen as more practical to the modern housewife were stressed over more traditional styles like smettvev. Additionally, more universal styles were taught, further eliminating indigenous practical items like kvitla. In keeping with the proliferation of Danish-influenced 'folk schools' throughout the Nordic region, the school brought in teachers from outside the community to instruct students in home-crafts. Jorunn remembers a Danish weaving instructor from her days at the Heimyrkjeskule.

\section{0-PRESENT: AN ERA OF HERITAGE}

In the 1960s and 1970s, the Norwegian economy underwent a dramatic change after the government began extracting oil from its maritime territories in the North Sea. Continued extraction and fruitful investment strategies brought substantial economic growth to Norway in the decades that followed. While Norway had historically been one of the poorest of the Scandinavian nations, by the 1990s it had surpassed its neighbours and former colonisers Sweden and Denmark in economic growth and capital for the first time in centuries (Røed Larsen 2006: 606). These profound economic changes thus led to a period of intense urbanisation and centralisation in Norway, and in Jølster, this translated to many people abandoning life on farms in small villages for jobs in the larger towns. 
The village I spent the summer living in, Sanddalen, is a good example of this. Before the 1970s, Sanddalen had a population of about 70 people, and many families in the village had children. The village had its own store and primary school. In the 1970s, the school closed, and the children were sent to the larger town of Vassenden. Gradually, people filtered out and the store closed as well. The owner, Ingvald Hylderås, told me that he could not compete with the chain stores that were popping up in larger towns like Vassenden and Skei. Now that nearly everyone had access to transit by automobile, it was cheaper and more efficient for villagers to drive to the central towns and do their shopping where the selection was greater and the prices lower. Today Sanddalen has a population of about 30, and only a few families have children. In previous years, the village was full of small farms scattered throughout the valley, but today a select few farms dominate, some operated by single families or individuals, and others operated by multiple families who have chosen to consolidate their herds and facilities in hopes of lower production costs and greater returns. (Interview with Arne Reidar Solheimsnes, 2014) This pattern is a common one in Jølster, and it has become more so in recent years as increasingly neoliberal federal government policies bring in cheap food imports from other countries and legislation is passed in Norway favouring large, mechanised farming operations (Brennpunkt 2016). Meanwhile, small farmers in Jølster and elsewhere were actively protesting against these trends locally and at coordinated events in cities during my fieldwork in the summer of 2014 (see Photo 5).

Educational expectations and realities also changed to accommodate the new system. Many of my older sources, like Svanhild and Brita, received little to no formal education, but noted that by the time they had children, education through high school was an expectation. This left little time or need for learning traditional handicrafts in

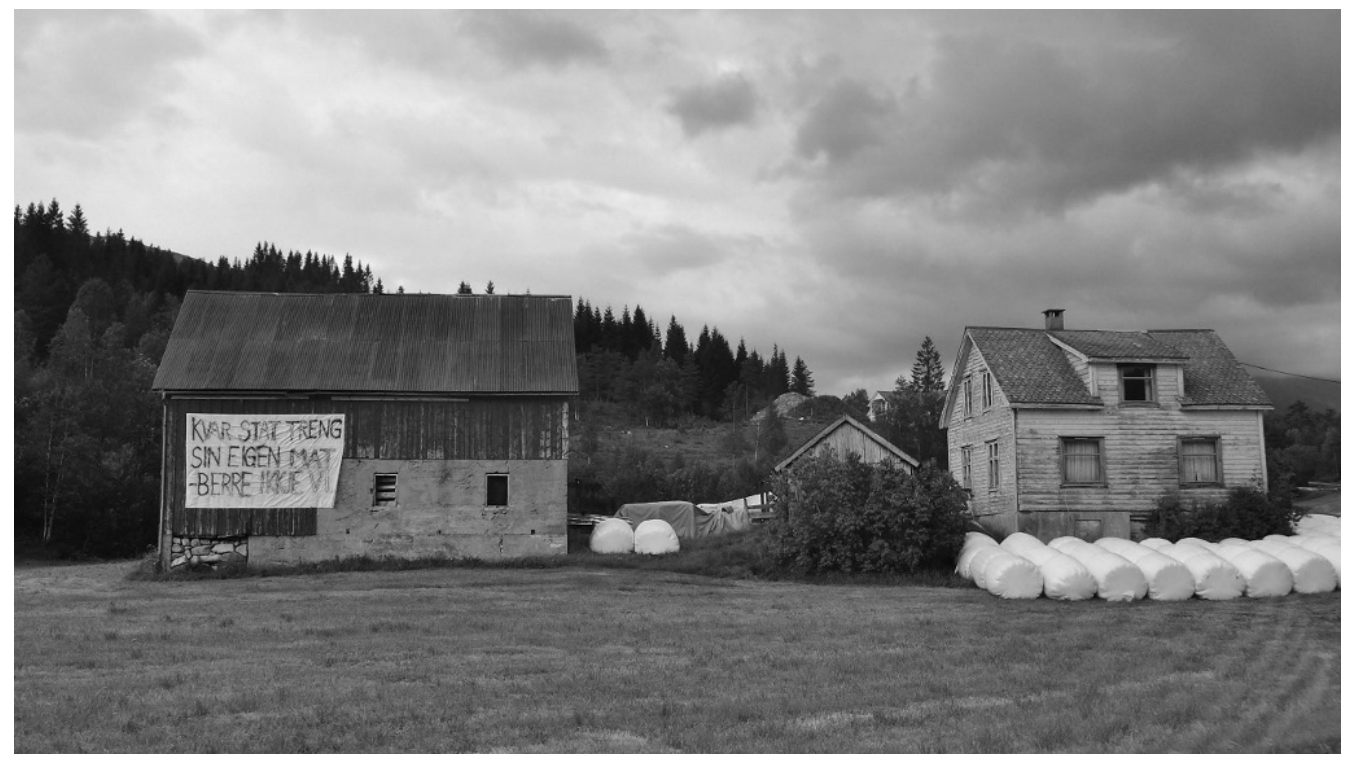

Photo 5. An empty farm near Vassenden i Jølster, bearing a sign reading "Every nation needs its own foodjust not us". Protest signs and art responding to national farm politics peppered the landscape in Jølster during the summer of 2014. Photo by Colin Connors. 
the home. The Heimyrkjeskule continued as a trade high school under the name Mo og Jølster vidaregåandeskule (Mo and Jølster High School), and other schools and courses like it sprung up around the area periodically. But in June of 2014, Mo og Jølster vidaregåandeskule closed its doors for good as a part of centralisation efforts by the government of Sogn og Fjordane. During my time in Jølster that summer, I heard many locals express their dismay at the school's closing. An emigration of young people seeking education and jobs has been on-going in the Jølster for some time, and this most recent development would mean area youth spending even less time immersed in what many jølstringar described to me as their "native" landscape and culture.

For some, the push out has also meant an incentive to return with an even stronger feeling of belonging to this landscape and its history, a phenomenon I see as indicative of contemporary folk reflexivity in Jølster. Jeweller and metalworker Anne Lise Øvrebø (b. 1978) returned to her native village of Ålhus for artistic inspiration after several years spent away at schools and apprenticeships. She now lives full-time in this hamlet of about 100 people with her husband and children, and owns Øvrebø Smykkeverkstad (Øvrebø jewelry workshop). Anne Lise attended Mo og Jølster videregåandeskule as a teenager studying art and metalworking. She eventually went on to an apprenticeship program in filigree, working under jewellery makers ${ }^{14}$ in the southern Norwegian district of Setesdal, and then apprenticed under a goldsmith in Oslo. She said that she chose her profession because she needed something she could "leve av" ('live off', 'survive on') and "leve for" ('live for'), citing her desire to stay in her hometown, creating pieces that are grounded in her sense of place and person. Her current work is thus sleek and modern, but is strongly influenced by her training in traditional techniques and her identity as a jølstring.

Anne Lise said she grew up in a traditional community, surrounded by local art and smettvev tapestries, and learned to weave as a child. While she never became a serious weaver, Anne Lise inherited her grandmother's pattern book, and used a samrose motif to create a line of smett-inspired jewellery for her business (see Photo 6). Much of Anne Lise's other work likewise takes influence from forms that characterise Jølster, such as a line of jewellery featuring the floral symbol of Audun Hugleikson, a successful medieval chieftain from Jølster, as well as a collection modelled after an åkle tapestry designed by Nikolai Astrup (1880-1928), a local artist revered in the area. Some of her most popular items are from her "jølstring" collection, a line of necklaces and cuff links stamped variously with the texts "jølstring", "halv ['half'] jølstring", "kvart ['quarter'] jølstring", and "wannabe jølstring."

Anne Lise's example demonstrates the many layers through which the individual's perception of heritage is formed. Anne Lise's heritage and identity is defined not only by her experience as a native of Jølster immersed in the artistic forms of this locale, but also by her experiences living in other areas of Norway and being educated in other artistic pedagogies, both localised and globalised. An individual's perception of identity does not occur in a vacuum, but rather is formed using frames of reference acquired through experiences both within and outside of the community. Furthermore, heritage is defined locally by the community and the individual, who choose those things they wish to celebrate. However, heritage also defines the community and the individual, shaping identity and sense of self. As the Norwegian scholar Mikkel Tinn (2011: 213) argues, self-perception is firstly predicated upon cultural situation: "Long before we 


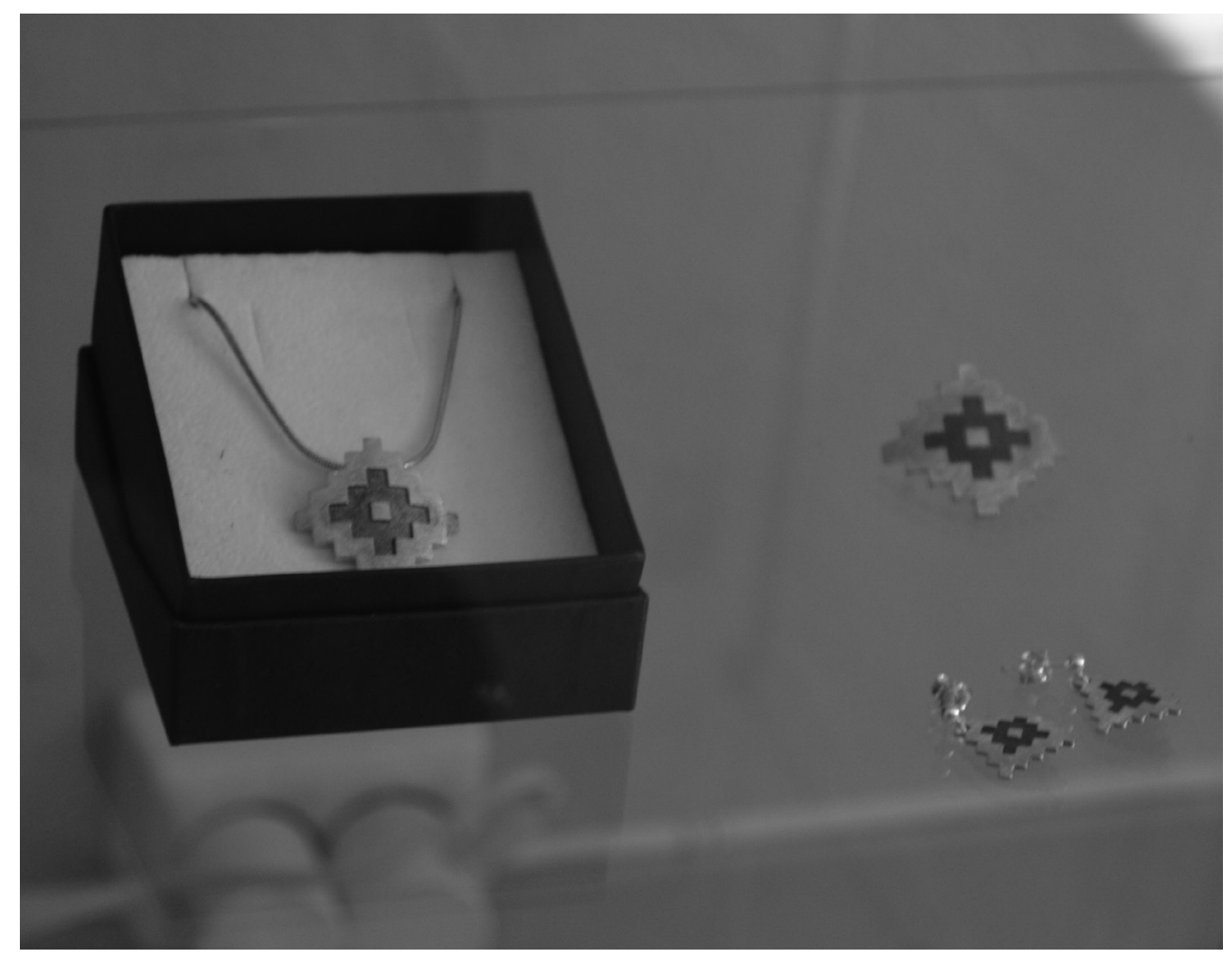

Photo 6. Anne Lise Øvrebø's "Åkle" line of jewelry, featuring a samrose motif. Photo by the author.

understand ourselves through self-reflection, we understand ourselves through family, society, and state".${ }^{15}$ Heritage therefore shapes our self-perception, even as we shape it through our social imagination and layers of experience. Heritage is a kind of collective memory that we fashion and codify, and the way that we shape it says as much about our perceptual identities as does the content of the heritage itself. Tinn (ibid.: 209) quotes Edmund Husserl's declaration that "tradition is the power to forget the origins", acknowledging that we not only receive heritage as a timeless inheritance, but also construct and shape it to reflect our own lives and what we want to believe about them, even as those who came before us shaped tradition to their situations. Tinn posits that traditions must therefore have "living meaning" - i.e. relevance in the multifaceted lives of their practitioners - in order for them to continue. Heritage is thus necessarily constructed, transforming in tandem with the lives of its practitioners, and thereby maintains its relevance. It has likewise been noted elsewhere that tradition, while popularly conceived of as a token of the past, is in fact "an aspect of contemporary social and cultural organization" (Williams 1977: 116; emphasis original).

For Anne-Britt Lotsberg (b. 1968), an occupational weaver in the county of Eid about an hour north of Jølster, maintaining the contemporary relevance of smettvev is vital to the continued success of her home business. Anne-Britt grew up in Fjærland, a village located on the other side of the glacier Jostedalsbreen from Jølster. Fjærland was 
kept relatively isolated well into the late 20th century for lack of roads, and is known for its particularly long-lived weaving tradition, which shows many holdovers from older forms that have disappeared in other areas. For example, unlike weavers in Jølster, who have been weaving on more mainstream flat looms for several generations, ${ }^{16}$ contemporary weavers of Fjærland continue to use old-style upright looms (see Photo 7). Growing up in Fjærland, Anne-Britt was surrounded by women weavers and other artisans, including her boat building grandfather and her mother, whom she said had a gift for drawing. Anne-Britt said she has always been particularly interested in smettvev, and started copying her grandmother's colourful weaving patterns onto graph paper as a child (see Photo 8). Eventually, she branched out to collect patterns from around Fjærland, going from farm to farm with her notebook and taking down patterns from women, "because everybody had something different". During our interview, AnneBritt offered something of a genealogy of her interest in weaving, saying she started out copying down patterns because they were nice to look at, and gradually became more aware of the heritage value of the art form as she grew older: "When I started drawing patterns, that was when I started thinking that it was nice to preserve them. Well, collect; yes, it was mostly about collecting. Preserving them came after."

Many local women, including Anne-Britt's grandmother, were connected to the tourist souvenir trade that grew up around the village's main attraction, the glacier Jostedalsbreen. The language Anne-Britt used to talk about the women who wove for produc-

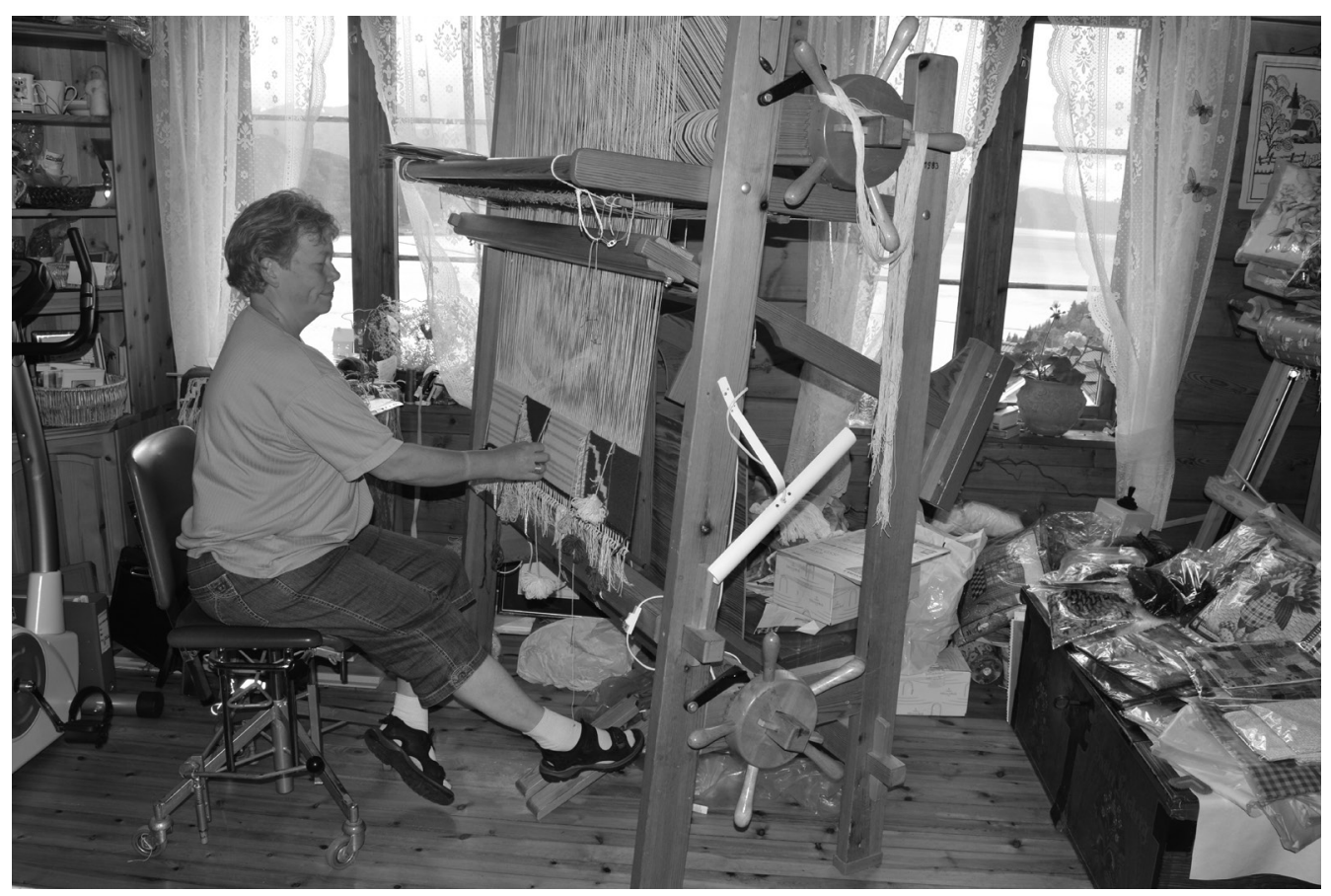

Photo 7. Anne-Britt Lotsberg at her loom working on a commissioned smett tapestry with non-traditional heart motifs for an upcoming wedding. Photo by the author. 


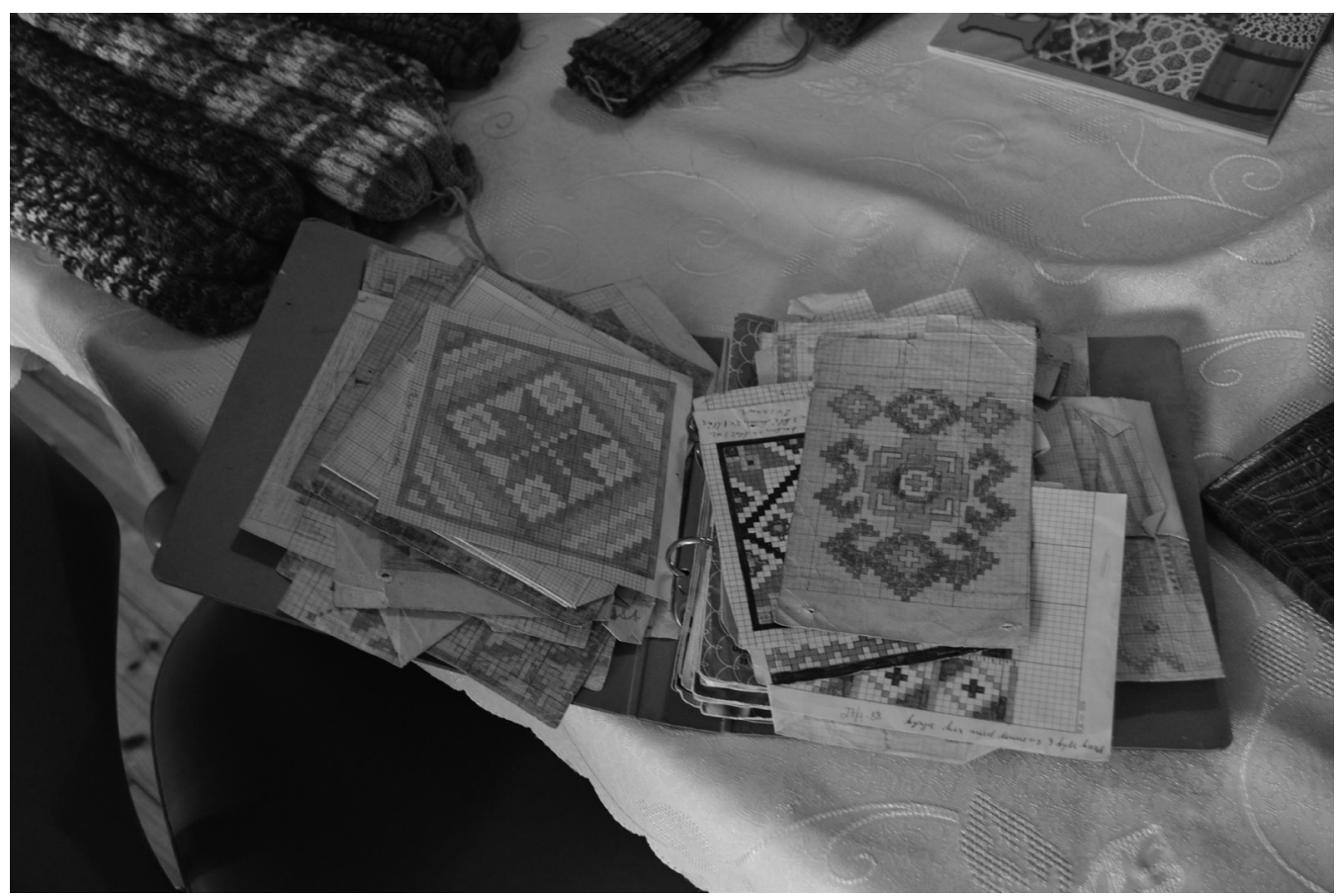

Photo 8. Anne Britt Lotsberg's pattern collection. Photo by the author.

tion alludes to this, as she said they wove "til breen" ('for the glacier'). Hotel Mundal, Fjærland's tourist resort, employed many women weavers to decorate its spaces and provide souvenirs for its customers. Anne-Britt recalled the gutting of the hotel that she witnessed as girl, and expressed her relief that she managed to get pictures of some of the largest and most impressive tapestries before they were thrown into the dump:

But think about [all the patterns] I have managed to collect, because I know that much of it has just burned. When they cleaned up after all these old ladies who died and didn't have kids... And the people who cleaned up, they didn't see the value - and this was what happened at the hotel too - and they chucked it all! They chucked tapestries, rugs - such luxurious ${ }^{17}$ tapestries; they were so luxurious. They had a loom at the hotel that was five meters long. You know, they could fit five ladies on the bench when they were making big rugs. I have a picture from one. Or a pattern, yeah. And that one - At that point they had cleaned out the hotel... And they were going to renovate, and they wanted a wooden floor rather than the carpeted one, so they pulled out all these fine tapestries. And I just thought, "Oh!" And it all went right in Kaupangerskogen, in the landfill. Right in the landfill, you know? And I am so glad, I managed to - I dared not go in and ask - think about if I had asked if I could have it, you know? No, I didn't dare do that. I wasn't that old yet. But I took pictures of it. Snuck up there and took pictures of it.

In 2000, Anne Britt quit her day job working for the county government and started weaving full time, selling her wares by word of mouth. She said that her customers 
are mainly Norwegians, locals and people from other areas of the country, like Hordaland, a province several hours to the south that has its own localised version of smettvev. Anne Britt said she gets most of her income weaving large, commissioned pieces for special occasions like weddings, confirmations, and business openings. She also keeps a stock of smaller items, like runners and pillow covers, and said a lot of customers buy these items to decorate their cabins, which they want to look traditional. Despite the traditional qualities inherent in Anne-Britt's craft, however, she is in fact continually transforming her style to fit the aesthetic sensibilities of a younger audience. During my visit, she showed me a stack of 'modern' runners featuring a traditional pattern, but woven with more a conventionally fashionable colour scheme (see Photo 9). A tapestry featuring a non-traditional, asymmetrical heart pattern was in progress on the loom, a commissioned piece for an upcoming wedding. While she staunchly maintains her use of traditional techniques, weaving on the old-style upright looms of her home village, Anne-Britt told me that she is not afraid to bend the rules to create innova-

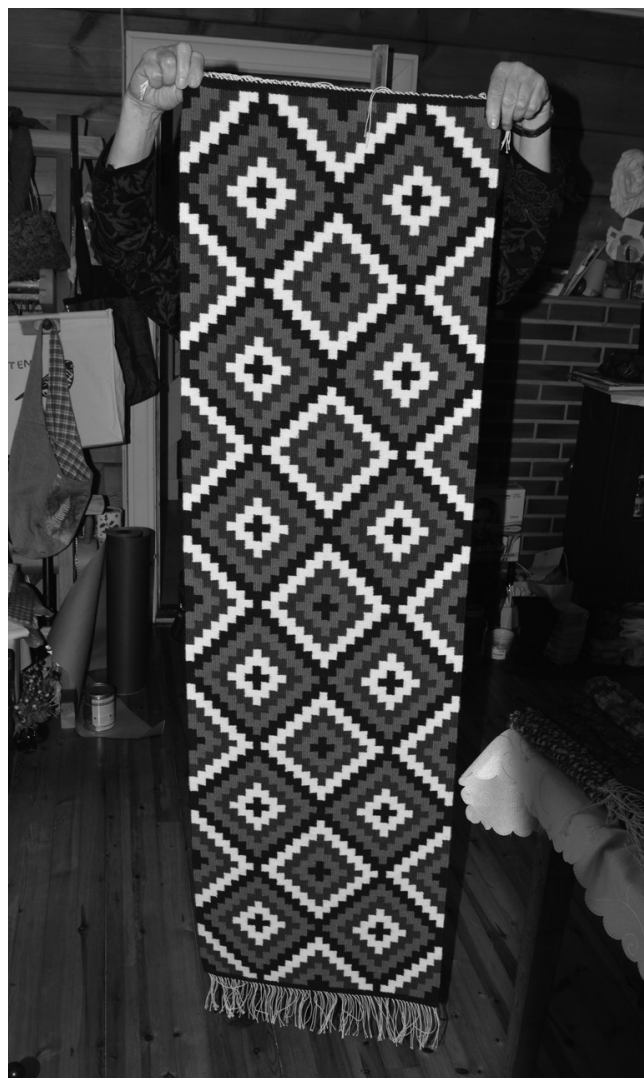

Photo 9. A runner by Anne-Britt Lotsberg featuring the traditional samrose pattern woven in a contemporary colour scheme, corresponding shades of blue. Photo by the author. tive pieces that younger people will want to buy. She said that keeping her products interesting to younger generations is a key part of maintaining a successful business over the long term. Anne Britt also does a variety of other fibre arts like knitting, quilting, and embroidery, and keeps a stock of these items on hand to fill gaps in income between her sales of lucrative tapestries.

Despite her thoroughly modern and nuanced approach to traditional weaving, Anne-Britt's community conceptualises her craft with a more nostalgic gaze. In October of 2014, Anne-Britt was featured on the popular Norwegian television program Norge Rundt. Anne-Britt's segment, which was entitled "Ho har ein utryddingstrua hobby" ('She has an endangered hobby'), opens on a scene of Anne-Britt sitting outside her husband's ancestral home, putting the finishing touches to a tapestry whose pattern, the narrator announces, dates back to the 13th century. The segment goes on detail how Anne-Britt's craft had been placed on the raudliste ('red list'), a list of endangered cultural practices and art forms curated by the Sogn og Fjordane Husflidslag ${ }^{18}$ (2014). This particular media portrayal is certainly an example of how her craft is exoticised and romanticised by the broader Norwegian society. Whereas this practice is a way of life for Anne-Britt that is simultaneously traditional but also moulded to fit her contemporary situation, for 
popular Norwegian society, it is a dying craft reminiscent of a previous era. Anne-Britt appears cognisant of the ways in which she is exoticised, joking in our interview about how she has become "utdøyande rase" ('a dying race').

To complicate this notion, it can be said that the segment also gives publicity and a platform to Anne-Britt as a traditional artist, which she then uses to further her own ends. Robert Baron (2010: 66) argues that, although

[c]ommunity members and their cultures may be objectified, but at the same time they may exercise agency to provide perspectives about their traditions on their own terms, advance their interests, and enable their traditions to flourish anew as a result of exposure to new audiences.

My interactions with Anne-Britt have demonstrated to me that she is proud to be a part of revitalisation and documentation efforts, and similarly takes advantage of the platforms she is provided through local arts organisations and the popular media to perpetuate smett weaving in the region. Anne-Britt is passing along her craft to her two young sons as well as to an interested neighbour girl, and voiced her desire to continue this living tradition in the Norge Rundt segment:

We get to see to it that this doesn't all go in the book of forgotten lore. Now we get to try and see if we can teach someone after-all. I want to do my part to make sure it doesn't die out. (Bakke 2014)

Anne-Britt's example is not an uncommon one. Nostalgia is a powerful and, arguably, productive force that has allowed for the commodification and exchange of traditional cultural forms for economic and social gain (Kirshenblatt-Gimblett 1995; Cashman 2006). Often, traditional artists must consciously shape and curate their forms to make them desirable by the consumer audience, a phenomenon folklorist Andrew Causey (1999) refers to as conflation. Causey describes conflation as happening through the transfer of traditional forms to non-traditional media as the subject of his study, a Toba Batak woodcarver named Partoho, uses ritual styles and motifs to decorate a secular, Western-style table lamp, which Partoho hopes to market to tourists. This shaping and curating can also occur in the way that traditional arts are talked about and conceptualised, as in the example of Anne-Britt in the Norge Rundt special, where the 'ancientness' of her craft was highlighted by proximity to an historic building and references to the medieval age. The validation of traditional arts through the exaggeration of ancientness, characterisation of art forms as static and timeless, and the invoking of the nostalgic gaze has been well documented elsewhere as a mode through which folklife is commodified and understood by consumers, both native and tourist (Boon 1982: 26; Graburn 1984; Simpson 1993: 166-168; Becker 1998; Goertzen 2010).

\section{FROM WEAVING TO BRANDING}

While only a handful of individuals remain who regularly weave smett, its associated symbols and motifs are being re-appropriated in new ways to represent identity. Examples of this include the translation of traditional smettvev motifs into other media by artisans like Anne Lise Øvrebø and Kari ‘Kajsa' Astrup Geelmuyden, a local potter who 
stamps her pieces with smett designs (see Photo 10). Jølstringar are also reappropriating smett into a symbol at the institutional level. An example of this is the logo adopted by the county government of Jølster a few years ago featuring the common klo pattern, a simple but ancient motif that is the basis for many other designs. The fact that the government chose to represent itself with this motif rather than another, more nuanced or contemporary pattern demonstrates their desire to harken back to 'origins' and to identify with ancestors. Additionally, their decision to depict this pattern in a colour scheme that was most common in the era before synthetic dyes ${ }^{19}$ shows their willingness to remember and preserve an 'authentic' time that, in reality, few people alive in Jølster today still remember. The extraction of this motif from its traditional form and context, and its re-appropriation as an official identity symbol represent the transformation of this art form into an "instantly recognizable," "infinitely reproducible" metonym for jølstringar (Anderson 1983: 175). Furthermore, the contemporary, non-traditional applications of smett designs show them to be a mode by which the temporal space of the past and the temporal space of the present are connected through images and symbols (Tuan 2004: 10-15).

Smett has become a successful brand symbol in Jølster over the past few years as this art form is re-appropriated into the popular culture. Smett designs can now be found in silk screened clothing items and mass produced accessories, and as advertising logos

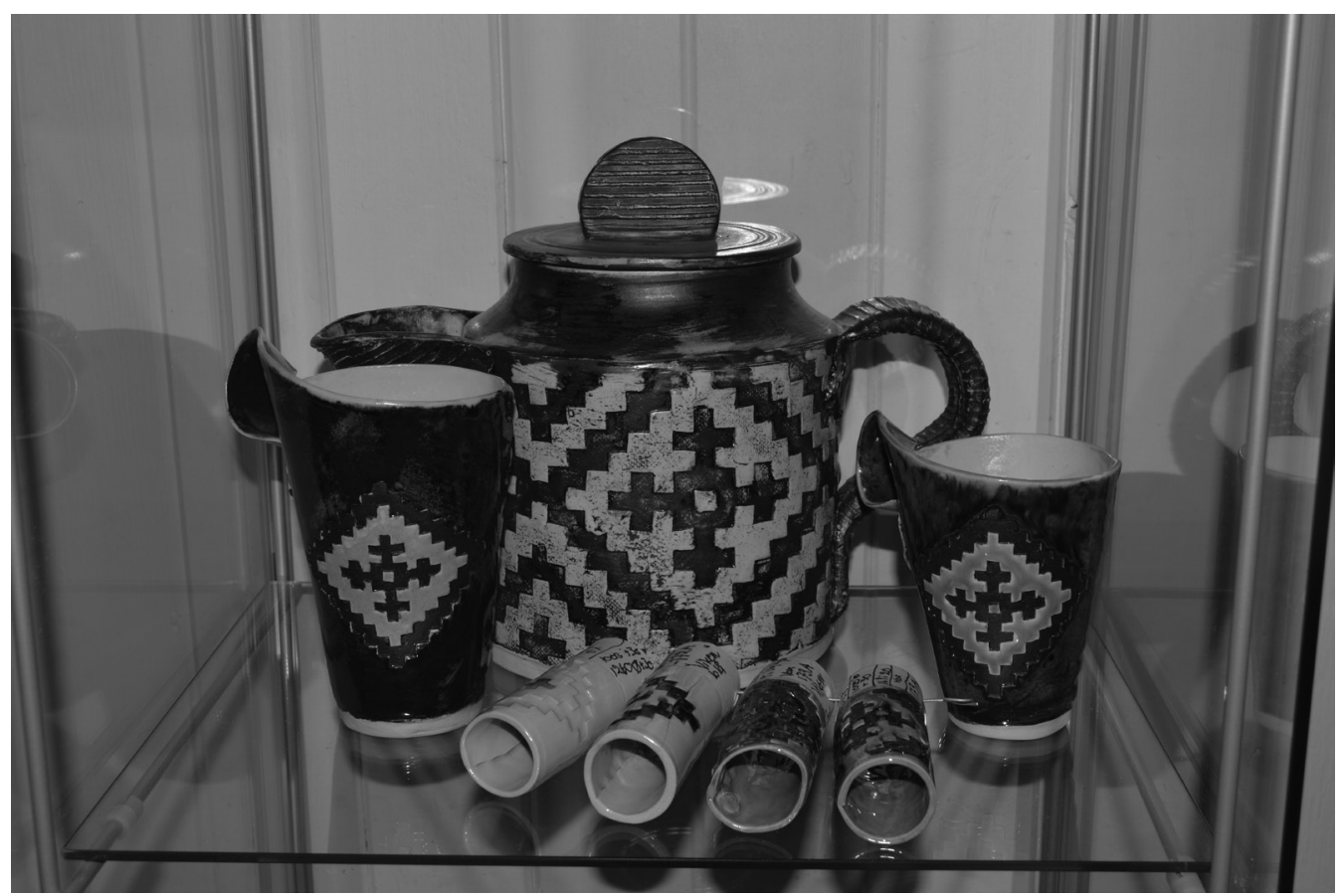

Photo 10. Pottery by Kari Astrup Geelmuyden stamped with the klo pattern. Photo by the author.

for local events like Aurefest, a popular summer fishing competition and festival in Jølster. In 2014, the winner of the fishing competition received a new car featuring custom smett decals. This prize was so popular, the festival organisers have continued to repeat this concept in the years since, and again in 2017 the winner of Aurefest will drive off 
with their own sleek automobile stamped with regional symbols, a prime example of the navigation of the local and the global, the ancient and the modern, happening in contemporary Jølster.

The re-appropriation of smettvev as heritage art and identity symbol represents the agency jølstringar have in understanding, shaping, and responding to their current context as this symbol becomes a medium through which locals negotiate their positions as both natives of this district and participants in the global culture and economy. The uses of smett motifs in official discourse, commercial production, and in the artistic creations of jølstringar thus represent the reflexive reinterpretation of this craft as a heritage art through agentive negotiations by the folk.

\section{NOTES}

1 The word åkler ('tapestries') is used in this article to refer specifically to tapestries done in the traditional geometric style know as smett or smettvev, the focus of this study. Same as smettakler.

$2 \mathrm{Smett}$ is a geometric tapestry-weave style known in various localised forms across Western Norway. In Jølster, smett can be done in either dobbelslyng or enkelslyng (double-interlocking or single-interlocking weft). For further technical descriptions of this style and examples of patterns, see Myklebust 2013, Noss 2005, Ramstad 2005, and the collections of Sunnfjord Museum in Førde, Norway.

3 The words smett and smettvev will be used interchangeably throughout this article.

4 Demonym; people from Jølster. Singular: jølstring.

5 My fieldwork collection from that summer includes 424 digital photos, 7 digitally recorded interviews, and approximately 50 pages of field notes. The pool of people I interacted with directly for this research through formal interviews (some digitally recorded and some simply notated) and visits numbers about 20. My interactions with research participants often happened through material objects, such as by sitting with an individual and asking questions as we looked through their tapestry collection or watching and even sometimes participating as an individual demonstrated techniques on the loom or spinning wheel. Interview participants were more or less invited to tell freely, with guiding questions along the way. The questions I asked to guide my interviews varied from person to person, but often focused on how this particular individual had come to learn the craft or about the craft; what the craft had meant to them growing up; and what the craft meant to them in their contemporary life. Older participants were solicited for more in-depth histories of smettvev in the region, whereas younger participants were relied on to give information about the relevance of smettvev for younger generations in the contemporary era.

6 Certainly, the economic development of Jølster is more complex than my superficial outline suggests. Capitalism had been present in the area for centuries as feudal lords and their families exploited the labour and environmental resources of the region in their dealings with external commercial entities, such as the Hanseatic League, which had a strong presence in nearby Bergen. Indeed, the feudal model is a relatively recent memory in Jølster, as my interview with Arne Reidar Solheimsnes (2014) about the geography and history of Sanddalen indicated. Jølster also lies along a historic thoroughfare from Bergen to Trondheim, and many of the older people I met during my fieldwork who had grown up before a modern automobile road was built recalled travelling tailors, salesmen, migrant Romani, and others moving through their villages and at times even requesting room and board at their farms. People from this region furthermore experienced transnational contact through friends and relatives who immigrated to the United States in droves during the 19th and 20th centuries. Many jølstringar who remained at home received letters and care packages from Norwegian-American relatives, and some immigrants even returned 
home to Jølster after a time, bringing new ideas and new money back with them. Therefore, by suggesting that the local economy in this region has transformed from subsistence to capitalist over the course of the past hundred years or so, I do not intend to deny the obviously complex economic history of this region. Rather, I mean to focus on the ongoing period of intense change as experienced by everyday jølstringar over the course of the past century. While this period is not unprecedented in the changes that it brings, it has certainly brought sweeping change at a faster rate than ever before.

7 Kvitla are traditional, all-purpose woolen blankets. They are usually white with blue stripes and edging. These blankets were a ubiquitous household accessory in pre-industrial Jølster, but my interactions with locals indicate that they have lost a degree of social capital in the contemporary era.

8 Scholars have elsewhere noted the survivalist factors that have led to the commodification of folk arts. See Spooner 1986: 214-220; Causey 1999: 424-425.

9 A vevstove is a traditional building on a farm reserved for weaving.

10 The Vikens have in recent years turned their attentions away from marketing local smett products in favour of supplying more mass-produced items that sell well amongst tourists. Conversations with Hallvard have indicated to me that he no longer sees the sale of local hand weavings as a sustainable venture. However, the Vikens have started a line of mass-produced accessories featuring smell designs.

11 A small factory for producing dairy products like butter and cheese.

12 In 1950s-1960s currency; today, large tapestries go for around 4,000 kr, which is around $\$ 500$.

13 While fashions have certainly changed in Jølster, it is still common to give a tapestry for a special occasion like a wedding, confirmation, or business/building opening. Workers at Jølster Design, a hand weaving business located in the village of Myklebust, told me that most of their custom orders are for these kinds of events. However, while the rituals surrounding giving such textiles are traditional, the tapestries themselves are often not. Jølster Design, for example, specialises in computer assisted hand weaving on jacquard looms, and produces very modern artworks that are sometimes based on photographs of people or landscapes.

14 Hasla, the company where Anne Lise apprenticed makes both contemporary pieces and traditional Norwegian jewellery known as sølje. Anne Lise learned to make a kind of sølje native to the Setesdal region during her apprenticeship. While visiting with her in her workshop, I noticed she had a large traditional pin she made hanging alongside the diploma she received for graduating her apprenticeship.

15 My translation.

16 None of the weavers I talked to in Jølster, even the eldest informants, had ever seen anyone weaving on an upright loom. Many even seemed a bit confused by my descriptions of such looms when I asked, implying that this concept was entirely foreign to them. However, despite the fact that looms in Jølster are in the flat style, many weavers continue to keep their warp taught using weights (ljodd), a more archaic mode not found in a lot of mainstream Western weaving.

17 Anne-Britt used the word digre, which can be more directly translated as 'thick' and implies the sturdiness and quality of these tapestries.

18 Sogn og Fjordane's provincial division of Norges Husflidslag, a national craft society sponsored by the Norwegian government and accredited as an NGO by UNESCO. Its raudlista ('red list') project seeks to identify and document endangered cultural practices in the region, and create programing and courses designed to perpetuate these endemic practices.

19 Red, black/brown, and yellow, the colors used in the logo, were easiest to achieve with the natural plant dyes most readily available in the region in pre-industrial times. 
Interview with Kari Astrup Geelmuyden. Årdal i Jølster, Norway; July 21, 2014. Interview with Jorunn Dvergsdal. Dvergsdal i Jølster, Norway; June 10, 2014. Interview with Brita Kongsvik. Myklebust i Jølster, Norway; May 30, 2014. Interview with Anne-Britt Lotsberg. Lotsberg i Eid, Norway; June 19, 2014. Interview with Arne Reidar Solheimsnes. Via Skype. November 16, 2014. Interview with Svanhild Åhaug. Ålhus i Jølster, Norway; June 2, 2014. Interview with Anne Lise Øvrebø. Ålhus i Jølster, Norway; July 21, 2014.

\section{REFERENCES}

Abrams, James F. 1994. Lost Frames of Reference: Sightings of History and Memory in Pennsylvania's Documentary Landscape. - Conserving Culture: A New Discourse of Heritage, edited by Mary Hufford. Chicago, IL: University of Illinois Press, 24-38.

Anderson, Benedict. 1983. Imagined Communities. London: Verso.

Appadurai, Arjun. 1996. Modernity at Large: Cultural Dimensions of Globalization. Minneapolis, MN: University of Minnesota Press.

Bakke, Heidi Lise. 2014. Ho har ein utryddingstrua hobby. Førde: NRK Sogn og Fjordane. http://www.nrk.no/sognogfjordane/ho-har-ein-utryddingstrua-hobby-1.11960173 (accessed December 2, 2016).

Baron, Robert. 2010. Sins of Objectification? Agency, Mediation, and Community Cultural SelfDetermination in Public Folklore and Cultural Tourism Programming. - Journal of American Folklore 123: 63-91. DOI: https://doi.org/10.5406/jamerfolk.123.487.0063.

Becker, Jane S. 1998. Selling Tradition: Appalachia and the Construction of an American Folk, 19301940. Chapel Hill, NC: University of North Carolina Press.

Boon, J. A. 1982. Other Tribes, Other Scribes: Symbolic Anthropology in the Comparative Study of Cultures, Histories, Religions and Texts. Cambridge: Cambridge University Press.

Brady, Erika. 1994. 'The River's Like Our Backyard': Tourism and Identity in the Ozark National Scenic Riverways. - Conserving Culture: A New Discourse of Heritage, edited by Mary Hufford. Chicago, IL: University of Illinois Press, 138-151.

Brennpunkt. 2016. Framtidsbonden.Oslo:NRK.https://tv.nrk.no/serie/brennpunkt/mddp11000116/ 16-02-2016 (accessed December 2, 2016).

Cashman, Ray. 2006. Critical Nostalgia and Material Culture in Northern Ireland. - The Journal of American Folklore 119 (472): 137-160. DOI: https://doi.org/10.1353/jaf.2006.0016.

Causey, Andrew. 1999. The Singasinga Table Lamp and the Toba Batak Art of Conflation. - The Journal of American Folklore 112 (445): 424-436. DOI: https://doi.org/10.2307/541370.

Dundes, Alan. 1966. Metafolklore and Oral Literary Criticism. - The Monist 50 (4): 505-516. DOI: https://doi.org/10.5840/monist196650436.

Feltault, Kelly 2006. Development Folklife: Human Security and Cultural Conservation. - Journal of American Folklore 119 (471): 90-110. DOI: https://doi.org/10.1353/jaf.2006.0006.

Førsund, Finn Borgen. 2001. Jølster: Hundre år med bygd og bank. Førde: Selja forlag.

Glassie, Henry. 1973. Structure and Function, Folklore and the Artifact. - Semiotica 7 (4): 313-351.

Glassie, Henry. 2003. Tradition. - Eight Words for the Study of Expressive Culture, edited by Burt Feintuch. Urbana, IL: University of Illinois Press.

Goertzen, Chris. 2010. Made in Mexico: Tradition, Tourism, and Political Ferment in Oaxaca. Jackson, MS: University Press of Mississippi.

Graburn, Nelson H. H. 1984. The Evolution of Tourist Arts. - Annals of Tourism Research 11: 393419. DOI: https://doi.org/10.1016/0160-7383(84)90029-X. 
Hufford, Mary, ed. 1994. Conserving Culture: A New Discourse of Heritage. Chicago, IL: University of Illinois Press.

Kirshenblatt-Gimblett, Barbara. 1995. Theorizing Heritage. - Ethnomusicology 39 (3): 367-380. DOI: https://doi.org/10.2307/924627.

Kirshenblatt-Gimblett, Barbara. 1998. Destination Culture: Tourism, Museums, and Heritage. Berkeley, CA: University of California Press.

Mondale, Clarence. 1994. Conserving a Problematic Past. - Conserving Culture: A New Discourse of Heritage, edited by Mary Hufford. Chicago, IL: University of Illinois Press, 15-23.

Myklebust, Bodil. 2013. Litt om åkle frå Jølster: ved Jølster Mållag og Aud Sunde, frå åkleregistreringa 1998. Førde. Unpublished manuscript.

Noss, Aagot. 2005. Jølster og den gamle klesskikken. Oslo: Novus forlag.

Ramstad, Eva. 2005. Åkle i Sogn og Fjordane: frå seng til vegg. Leikanger: Sogn og Fjordane Husflidslag / SKALD.

Røed Larsen, Erling. 2006. Escaping the Resource Curse and the Dutch Disease? When and Why Norway Caught up with and Forged Ahead of Its Neighbors. - American Journal of Economics and Sociology 65 (3): 605-640. DOI: https://doi.org/10.1111/j.1536-7150.2006.00476.x.

Salzman, Phillip Carl. 2002. On Reflexivity. - American Anthropologist 104 (3): 805-813. DOI: https://doi.org/10.1525/aa.2002.104.3.805.

Simpson, Bob. 1993. Tourism and Tradition: From Healing to Heritage. - Annals of Tourism Research 20: 164-181. DOI: https://doi.org/10.1016/0160-7383(93)90116-K.

Seitel, Peter, ed. 2001. Safeguarding Traditional Cultures: A Global Assessment. Washington, DC: Smithsonian Center for Folklife and Cultural Heritage.

Sogn og Fjordane Husflidslag. 2014. Raudlista: Handverksteknikkar. Flekke, Norway: Sogn og Fjordane Husflidslag.

Spooner, Brian. 1986. Weavers and Dealers: Authenticity and Oriental Carpets. - The Social Life of Things: Commodities in Cultural Perspective. Cambridge: Cambridge University Press.

Strauss, Anselm. 1956. The Social Psychology of George Herbert Mead. Chicago, IL: The University of Chicago Press.

Swain, Margaret B. 1993. Women Producers of Ethnic Arts. - Annals of Tourism Research 20: 31-55. DOI: https://doi.org/10.1016/0160-7383(93)90110-O.

Tinn, Mikkel. 2011. Spilleregler og spillerom: Tradisjonens estetikk. Oslo: Novus forlag.

Tuan, Yi-Fu. 2004. Place, Art, and Self. Santa Fe, NM: Center for American Places.

Urban Institute and The Fund for Folk Culture. 2003. Culture and Commerce: Traditional Arts in Economic Development. Washington, DC: The Urban Institute.

Widbom, Mats and Barbro Klein, eds. 1994. Swedish Folk Art: All Tradition is Change. New York, NY: Harry N. Abrams.

Whisnant, David. 1983. All That is Native and Fine: The Politics of Culture in an American Region. Chapel Hill, NC: University of North Carolina Press.

Williams, Raymond. 1977. Marxism and Literature. Oxford: Oxford University Press. 